\title{
MASTER
}

ORNL/TM-6090

\section{Systems Study for Initial Development of a Laboratory Records Information System}

\author{
L. J. Peck \\ C. R. Shriner
}

OAK RIDGE NATIONAL LABORATORY OPERATED BY UNION CARBIDE CORPORATION · FOR THE DEPARTMENT OF ENERGY 


\section{DISCLAIMER}

This report was prepared as an account of work sponsored by an agency of the United States Government. Neither the United States Government nor any agency Thereof, nor any of their employees, makes any warranty, express or implied, or assumes any legal liability or responsibility for the accuracy, completeness, or usefulness of any information, apparatus, product, or process disclosed, or represents that its use would not infringe privately owned rights. Reference herein to any specific commercial product, process, or service by trade name, trademark, manufacturer, or otherwise does not necessarily constitute or imply its endorsement, recommendation, or favoring by the United States Government or any agency thereof. The views and opinions of authors expressed herein do not necessarily state or reflect those of the United States Government or any agency thereof. 


\section{DISCLAIMER}

Portions of this document may be illegible in electronic image products. Images are produced from the best available original document. 
Printed in the United States of America. Available from National Technical Information Service

U.S. Department of Commerce

5285 Port Royal Road, Springfield, Virginia 22161

Price: Printed Copy $\$ 4.00 ;$ Microfiche $\$ 3.00$

This report was prepared as an account of work sponsored by an agency of the United States Government. Neither the United States Government nor any agency thereof, nor any of their employees, contractors, subcontractors, or their employees, makes any warranty, express or implied, nor assumes any legal liability or responsibility for any third party's use or the results of such use of any information, apparatus, product or process disclosed in this report, nor represents that its use by such third party would not infringe privately owned rights. 
Contract No. W-7405-eng-26

Information Division

SYSTEMS STUDY FOR INITIAL DEVELOPMENT

OF A LABORATORY RECORDS

INFORMATION SYSTEM

L. J. Peck and C. R. Shriner

Information Center Complex

Date Published - November 1977

This report was prepared as

sponsored by the prepared as an account of work sponsored by the United States Government. Neither the Enera States nor the United States Department of Energy, nor any of their employees, nor any of their any wark, theonkactors, or their employees, mekes liabity ox express or implied, or assumes any legal un use responsibility for the acruracy, completeness or usefulness of any information, spparalus, product or process disclosed, or represents that its use would net 
THIS PAGE

\section{WAS INTENTIONALLY \\ LEFT BLANK}




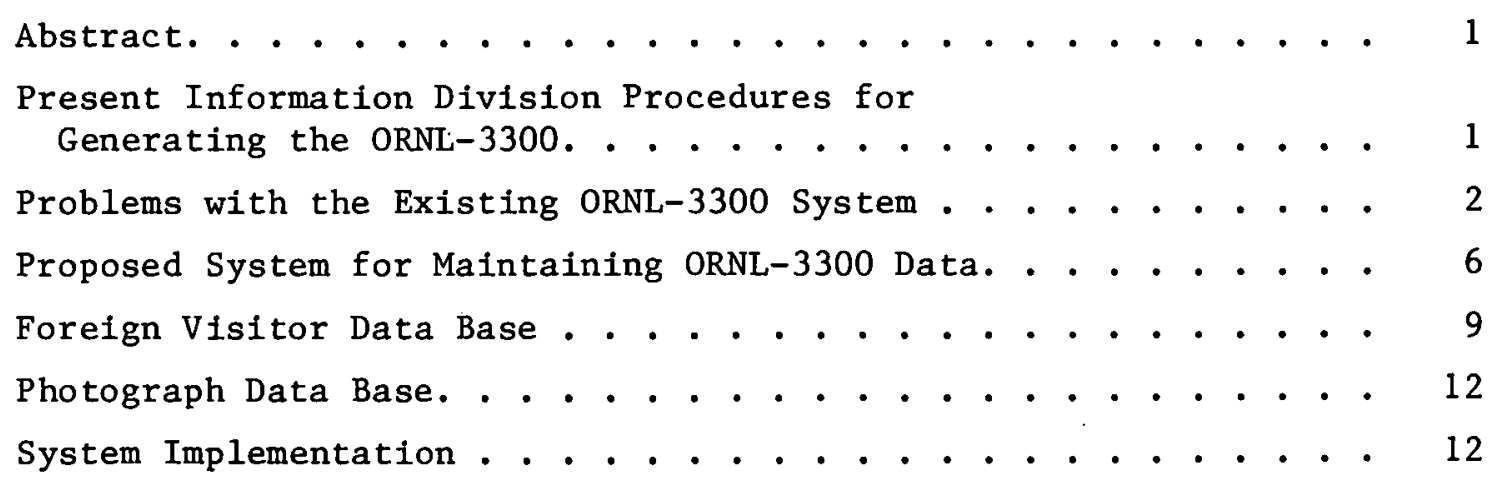


The major impetus for a system study of the ORNL Laboratory Records Department (LRD) was the ORNL-3300, a computer listing of all ORNL reports, papers, and oral presentations. Although this file has been maintained by the Information Division Libraries Department (LD) for several years, the usability of the file is somewhat limited, and duplicative steps appear to be involved in generation of the file. In order to examine procedures involved in generating the ORNL-3300, along with other Library Department and Laboratory Records Department procedures, various Information Division personnel were interviewed and the LRD Procedures Manual was reviewed. The existing LRD and LD procedures surrounding the ORNL-3300 were examined closely with the intent of developing an LRD computer data base from which the ORNL-3300 would be a by-product and which would eliminate duplicative manual procedures whenever possible. Integrating the ORNL-3300 into a computer data base system would allow Boolean logic searches on the 3300 data not possible with the present system. No attempt was made to examine ORNL-3300 facsimile data bases maintained by various divisions, although several are known to exist. Although addressing the ORNL-3300 is the major thrust of this paper, development of computer data bases for foreign visitors and ORNL photographs was also examined. In examining LRD procedures, only major components of system flow surrounding the ORNL-3300 were considered, and no attempt was made to examine other system alterations or LRD procedures which might be eliminated or computerized. No attempt will be made in this paper to explain in-depth details of LRD procedures since these are documented in the LRD Procedures Manual.

\section{PRESENT INFORMATION DIVISION PROCEDURES FOR GENERATING THE ORNL-3300}

The ORNL-3300 file is maintained by the Systems Development Office (SDO) in the Libraries Department. This group collects the information from the LRD, edits the information, has it keypunched, and maintains a punched card file of the information. Annually, a listing of the file with permuted title and author indexes is placed in the ORNL Central Research Library and the Y-12 libraries for use by ORNL personnel. 
General procedures for generating the ORNL-3300 are as follows:

1. For ORNL-numbered reports, a copy of the report title page and front cover is sent to the SDO where it is edited, marked, and sent to keypunch.

2. For papers and oral presentations, a Request for Declassification and/or Release (UCN-87A) form is marked and coded by LRD personnel. See Fig. 1 for an example of a marked UCN-87A form. The UCN-87A forms are accumulated for a workweek, then sorted by categories (speeches, publications, theses, or miscellaneous) and division. The forms are then sequentially stamped and sent to the SDO. Here the forms are edited and sent to keypunch.

3. Information is also collected for the ORNL-3300 file through use of the UCN-4217 data card (Fig. 2). This card is completed by LRD from reprints received, lists of published articles, and returned Journal Article Status (UCN-6284) forms. On a monthly basis, completed UCN-4217 cards are sorted by division, then by book or journal, xeroxed, and sent to SDO where they are edited and sent to keypunch. Keypunched information (Fig. 3) returned to SDO is placed in keypunch card files in the SDO. Data elements of the file are author, title, reference, and reprint information. On an annual basis, the accumulated cards are submitted with a computer program to generate a listing of the file with permuted title and author indexes. The annual output is placed in the ORNL Central Research Library and the Y-12 libraries for reference. Microfiche copies are also available.

PROBLEMS WITH THE EXISTING ORNL-3300 SYSTEM

Several problems related to the ORNL-3300 are as follows:

1. Although the ORNL-3300 data is in machine-readable form, the data is not part of the generalized information system and is therefore not machine searchable in a general mode. Computer programs exist for listing the data and producing permuted title and author indexes. 


\section{Ot - T REQUEST FOR DECLASSIFICATION AND/OR RELEASE SG-}

Submit copies 1.7 of form, properly executed 10 Laboratory Recerds Deparsment with (o) reproducibles or (b) 3 Xerox copies of document if no reproducible exists.

I. REQUEST: $\square$ Clossification and Potent Release $\sqsupset$ Declossitication OF THE ATTACHEO $\square$ Abstroct $\doteq$ Paper

2. TITLE: (Show in M $_{\text {snless clossified) }}$ $x$ OUTLINE

Shape Isonieriam in $84 \mathrm{Hg} \angle \mathrm{O}$.

67. AUTHOR: (List All Authors; if not an ORNL employee, indicate address on a seporote line) $D \phi N A$ ME ASTS 8

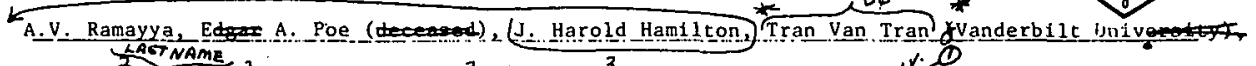

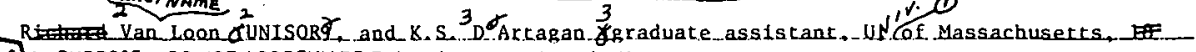
2 4. PURPOSE: DO NOT ABBREVIATE Tilles oi Meetings, Jourials, Uiviversitics

(a) Oral Presentotion (Give nome, place, andomet da

$18^{\text {th }}$

rator

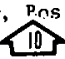

5

alinual 1 illeting of tile American.Phystcal Sociery, Q

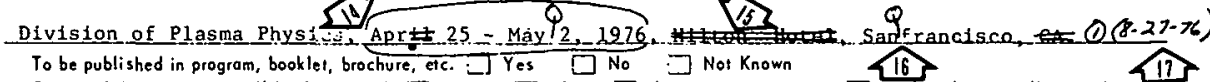
Copies of this document will be distributed $\square$ betore, $\square$ affer, $\square$ during the meeting, or $\square$ nodistribution will be mode. 17

(b) Publication (Proceedings of a meeting, give plaze and dates; Journal, give publication dote; Book, give editor ond publisher)

(c) No issued os o report $\square$ No $\square$ Yes (Number)

5. INVENTION5: (List Poge No. of any item appeoring to hove significont novelty; indicote il none.)

6. PREVIOUSLY CLEARED DOCUMENT: (Paper, abstract, progress report, etc., contoining similar information; indicate if clossified.)

1. Division code number

2. Category marking

3. Make words legible

Add 'space dash space' between items

5. Move to arrow

6. Change order of authors to match title page

7. Do not change names of foreign authors: nonemployee author

8. Abbreviate university delete parentheses period at end of line

9. Show order of nonemployee authors

10. Delete street addresses and states of famous cities

11. Change written numbers to Arabic

12. Delete unneeded words

13. Show space between information

14. Abbreviate months (except May, June. and July)

15. Delete hotels

16. Add needed space; delete state after famous city

17. Add date of

18. Delete publication name of an outline or abstract

DEADLINE DATE DIVISION Chemiscry _... AUTHOR _ Director Review Required

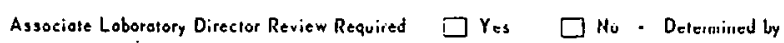

Division Director Project Director. Progrom Director APPROVALS

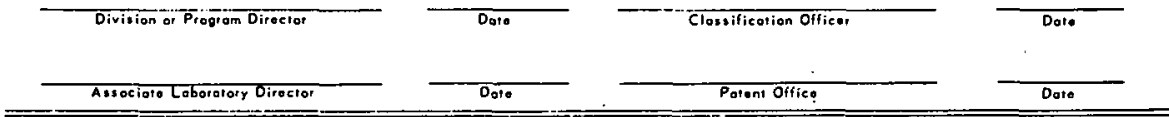

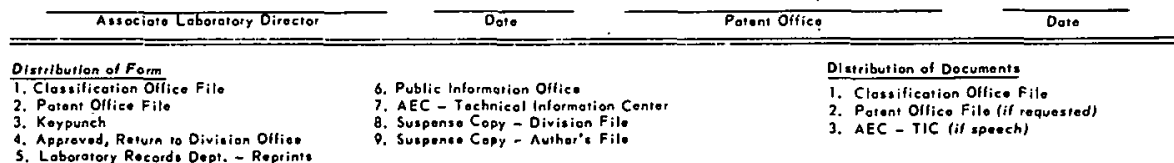

Fig. 1. Sample of a UCN-87A form, marked for keypunch, from the LRD Procedures Manual. The correlating style points are listed on the side. 
CODE NUMBER - LEAVE BLANK

02-56-6692

TITLE - DOUBLE SPACE IF POSSIBLE

Chromatin model calculations: array of spherical

bodies

\begin{tabular}{|c|c|}
\hline $\begin{array}{l}\text { AUTHORS - ALL OF THEM } \\
\text { Carlson, R. D. + Olins, D. }\end{array}$ & E. \\
\hline $\begin{array}{l}\text { REFERENCE } \\
\text { Nuc1. Acids Res. 3, 89-100 }\end{array}$ & $\begin{array}{l}\text { AVAIL ABILITY OR PRICES } \\
\text { (1976) Reprint }\end{array}$ \\
\hline 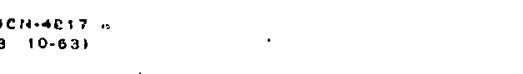 & 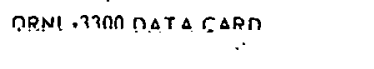 \\
\hline
\end{tabular}

LUUE NUMBER - LLAVE BLANK

$11-B 7-23090$

TITLE - DOUBLE SPACE IF POSSIBLE

Gap anisotropy and $T_{c}$ enhancement: general theory

aud calculationo for Nb using Fermi surface harmonics

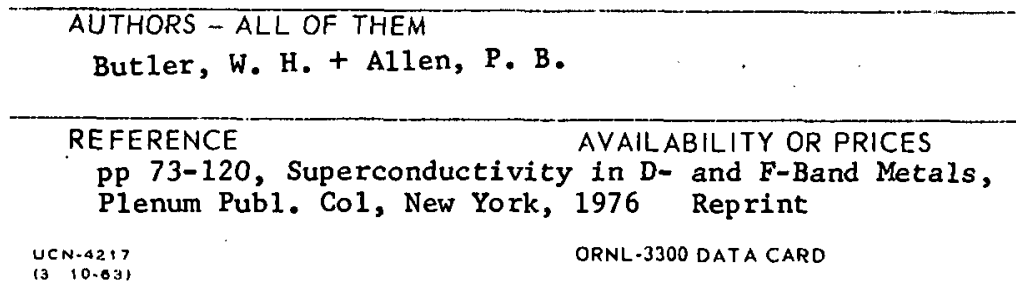

CODE NUMBER - LEAVE BLANK

O3-B7-23144

TITLE - DOUBLE SPACE IF POSSIBLE

Projections of wastes to be generated

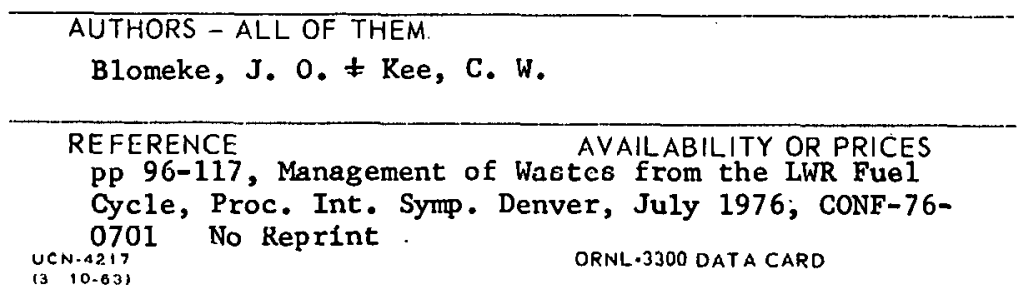

Fig. 2. Example of a UCN-4217 data card. 


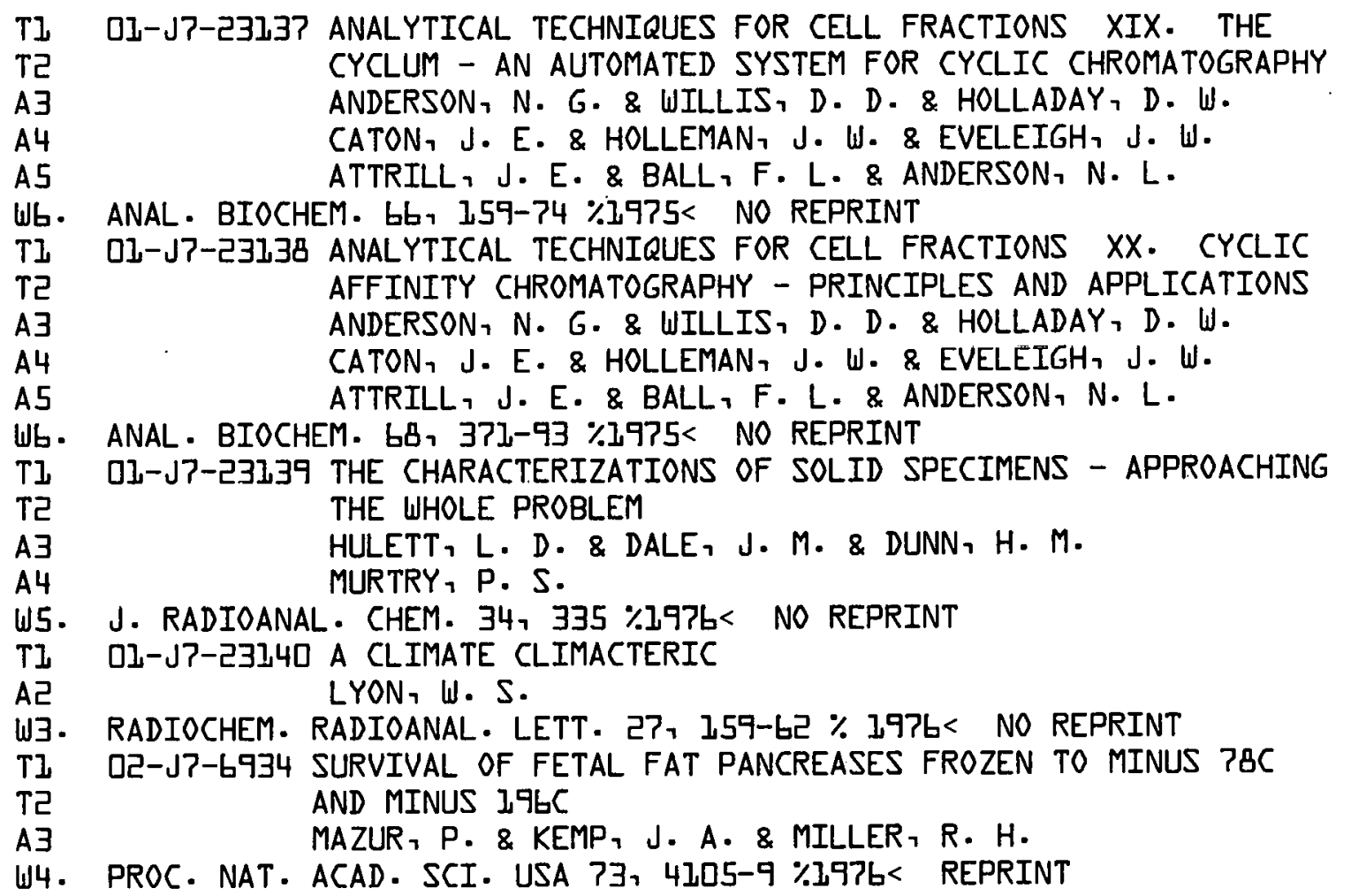

Fig. 3. Example of ORNL-3300 keypunched data.

Requests made to LRD for publication queries must be handled by manual searching.

2. A significant number of manual steps (e.g., coding, sorting, and stamping) are involved in generating the ORNL-3300 data.

3. The only dissemination of the present data is a computer listing with indexes placed annually in the ORNL Central Research Library and the Y-12 libraries.

4. There appears to be significant duplication of effort in maintaining publication data bases within the Information Division and the Laboratory.

5. The present ORNL-3300 does not have a mechanism for linking ORNL3300 data with speriflc ERDA piugrams. 
6. Under the present system, it is difficult for LRD to know when a paper or oral presentation has actually been accepted. Approximately $5 \%$ of papers and oral presentations processed through LRD are never accepted. Although implementation of an LRD. computer information system will not solve this problem, the data can be made much more accessible to each division and therefore possibly increase the data quality through feedback.

PROPOSED SYSTEM FOR MAINTAINING ORNL-3300 DATA

In proposing a system for LRD, an attempt has been made to decrease the number of procedures necessary for collecting the ORNL-3300 data. The key component in the recommendation is that the ORNL-3300 w111 be a computer data base in the Oak Ridge Computerized Hierarchical Information System (ORCHIS). As a data base in the ORCHIS, a wide array of search and dissemination capabilfties which do not presently exist with the ORNL-3300 data will be available.

The proposed system would involve placing a computer terminal in the LRD for data entry and Inquiry along with placing a terminal in the area manager's office for Inquiry purposes. A data base, of which the ORNL3300 data would be a subset, will be established utilizing the ORCHIS system. Table 1 gives a list of possible flelds for each record in the data base. The list of identifiers in Table 1 could be expanded substantially to serve the LRD requirements other than the ORNL-3300. LRD personnel will need to determine the exact field ldentifiers needed and their format for data entry prior to system implementation.

In the proposed system, data entry of the LRD information system data will take place in the LRD utilizing a computer terminal connected to the ORNL X-10 PDP-10 computer. The ORCHIS ADENTER program on the PDP-10 will allow prompted data input with syntax checking. Data entry can also be accomplished with terminals allowing forms mode data entry and local storage on tape cassette (Hewlett Packard); however, some software development cost would be incurred with this type of terminal. Typing the data into the computer directly from the UCN-87A form will eliminate marking, coding, sorting, photocopying, and mailing of the 
Table 1. Possible ORCHIS field names, codes, and descriptions for the LRD information system

\begin{tabular}{|c|c|c|}
\hline Field name & ORCHIS identifier & Description \\
\hline Author (s) & <AUTH> & $\begin{array}{l}\text { Author }(s) \text { of the paper or oral } \\
\text { presentation }\end{array}$ \\
\hline Title & $<$ TITL $>$ & Title of the paper or presentation \\
\hline Reference & $\langle$ REF $>$ & $\begin{array}{l}\text { Reference to publication in which the } \\
\text { paper or oral presentation appeared }\end{array}$ \\
\hline Reprint & $\langle\mathrm{REP}\rangle$ & $\begin{array}{l}\text { Code indicating whether or not reprints } \\
\text { are available }\end{array}$ \\
\hline Division & $\langle\mathrm{DIV}\rangle$ & $\begin{array}{l}\text { ORNL division code indicating where the } \\
\text { research was performed }\end{array}$ \\
\hline Budget category & $<$ BUD $>$ & ERDA budget and reporting classification \\
\hline Address & $<A D D R>$ & First author's ORNL address \\
\hline Document type & $<$ TYPE $>$ & $\begin{array}{l}\text { Type of document: speech, publication, } \\
\text { thesis, or ORNL report }\end{array}$ \\
\hline Publication date & $<$ PUB DATE $>$ & Publication date \\
\hline
\end{tabular}

UCN-87A form to the SDO. Also, keypunch costs will be eliminated. The entered data can be proofread and:edited by either LRD or LD personnel and then corrected online utilizing the PDP-10 TECO editor. On a weekly basis, edited data can be routed to the ORCHIS system on the ORNL X-10 IBM 360 computers. Here the data base can reside in magnetic tape format and also be avallable online for searching via the ORLOOK program. This assumes data base size does not exceed ORLOOK limitations and that sufficient disk space is available on the IBM 360 systems.

The present procedure for utilizing the UCN-4217 data card can be handled in the ORCHIS system exactly as the UCN-87A form is handled. Data normally typed onto the UCN-4217 card can be added to the ORCHIS record, via computer terminal, when a reprint order is processed by LRD or when other situations occur necessitating UCN-4217 type data. This will eliminate the necessity for the UCN-4217 card, which in turn eliminates typing, sorting, mailing, and keypunching of data from the card. 
In summary, entering ORNL-3300 data via a computer terminal and routing entered data to the ORCHIS are straightforward technique for generating and maintaining a data base and are routinely done by several ORNL divisions. No new software development is required. Actual implementation of the system will require slight operational procedure changes within the LRD. However, the number of manual tasks surrounding the ORNL-3300 should be significantly reduced. Advantages and possibilities for the system are summarized as follows:

1. The ORNL-3300 data along with other LRD data will be established as an ORCHIS data base. Therefore, Boolean logic searches on the data, online searching capability, a variety of output capability, indexing capability, merging, subsetting, etc., will be possible.

2. New information can be added to the ORCHIS data base on a weekly basis. Therefore, the data base will be reasonably current and available for searching at any time.

3. Having the ORNL-3300 data maintained in the ORCHIS system will bring the LRD closer to having a central data base for this type of information. Possibly, providing quarterly listings of reports, papers, and presentations with indexes to each ORNL division will encourage divisions to support the centralized data base in the LRD.

4. LRD will have the capability of providing ERDA and Laboratory management subsets of the data base by ERDA programmatic category.

5. Present procedures involving the UCN-4217 card will be eliminated. This includes typing the card, making xerographic copies, sorting the cards by division and category, mailing the cards to SDO, reviewing by SDO, and keypunching.

6. Present ORNL-3300 procedures involving the UCN-87A form can be eliminated. This includes marking, coding, sorting, stamping, photocopying, mailing to SDO, and keypunching of the forms.

7. Most procedures surrounding the Journal Article Status Inquiry (UCN-6289) form can be done automatically by computer. The data base could be searched for those records requiring an inquiry as 
to their status. Mailing labels could be generated automatically. A listing of the record could be mailed to the author with a request to correct or update the record.

8. With the ORNL-3300 resident in a generalized data base system (ORCHIS), the possibility of integrating machine-readable data from TIC and other divisions is significantly enhanced.

9. Typing of cross-reference cards and triplicate hand filing (three authors) of cards can be eliminated. A partial data base listing with author indexes can be generated on-a weekly basis.

10. Although some programming may be required, a portion of the LRD monthly report (e.g., documents received, number of speeches, number of publications, and number of theses) could be produced automatically by computer.

FOREIGN VISITOR DATA BASE

Generating a computer data base for foreign visitors can be accomplished in a manner similar to that recommended for the ORNL-3300 data. A mechanism for data collection is already available through the Noncitizen Visitor Approval Card (UCN-371A), an example of which is shown in Fig. 4. An ORCHIS record and corresponding prompted input program (ADENTER) can be structured from the information on this card. One possible ORCHIS structure for a furelgn visilur dala base is given in Table 2.

Data entry for the data base would be accomplished exactly as recommended for the ORNL-3300. Data from the UCN-371A card would be typed into the computer from the area manager's terminal, utilizing either the PDP-10 ADENTER program or a forms mode computer terminal. Following input, data could be edited on the PDP-10 TECO editor and then routed to the ORCHIS system on the IBM 360 computers. Any portion of the information on a card could be entered, with each record in the data base consisting of the data from one card.

Since the foreign visitor file is. large (approximately 25,000 cards), data entry should start with current monthly records and proceed back through the file, present to past. As is the case with the ORNL-3300, 
NON-CITIZEN VISITOR APPROVAL

\begin{tabular}{|c|c|c|}
\hline LAST NAME & MIODLE NAME & DATE(S) OF VISIT \\
\hline \multicolumn{2}{|c|}{ ORGANIZATION REPRESENTED } & VISIT REQUESTED BY: $\square$ EROA \\
\hline CITY & COUNTRY & FACILITY TO BE VISITEO: $\square$ ORNL $\square$ Y.12 \\
\hline CITIZENSIIIP & & RORTAL OR POST TO BE ENTERED \\
\hline DATE OF BIRTH* & CITY AND COUNTRY OF BIRTH ${ }^{+}$ & EUILOINGS TO OL VISITCD \\
\hline \multicolumn{2}{|r|}{ ] NON-IMMIGRANT. } & \\
\hline DATE OF ENTRY* & PORT OF ENTRY" & INDIVIDUAL(S) TO BE VISITED \\
\hline
\end{tabular}

$\begin{aligned} & \text { This Information is Required For Certain Countries. } \\ & \text { Check With Visitor Control Office, 3-6454. }\end{aligned}$
.

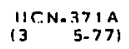

Fig. 4. Example of a noncitizen visttor approval card.

having the forelgn visitor file in machine-readable form in the ORCHIS system will allow a wide varlety of search and output capabilities. Boolean logic computer searching, along with indexes of visitors by country, person or facility visited, frequency counts, and summary listings are a few examples of the ORCHIS products possible. The present time-consuming hand searching of the file can be totally eliminated, and management can be provided quarterly or annual listings with indexes of visitors to various divisions.

Since searching the file may be the most important capability desired, some thought must be given to the type of searches to be performed so that the ORCHIS data base can be designed to meet the search objectives. For example, dates should be entered in numeric form (YYMMD) if searching in specific date ranges is desired. 
Table 2. Possible ORCHIS field names, codes, and descriptions for the foreign visitor data base

\begin{tabular}{|c|c|c|}
\hline Field name & ORCHIS identifier & Description \\
\hline Date requested & $<$ DATE REQ $>$ & Date visitor approval request made \\
\hline Name & $<$ NAME $>$ & Name of visitor \\
\hline Citizenship & $<$ CITZ> & Citizenship of visitor \\
\hline Date of birth & $<$ DATE BIR> & Date of birth \\
\hline Date(s) of visit & $<\mathrm{DAT}\rangle$ & Date(s) of visit \\
\hline Organization & $\langle O R G>$ & Organization the visitor is representing \\
\hline Facility & $<\mathrm{FAC}>$ & ORNL or Y-12 visited \\
\hline Building & $<\mathrm{BLD}\rangle$ & Building(s) to be visited \\
\hline Visited & $<$ VISITED $>$ & Individuals visited \\
\hline Purpose & $<$ PUR $>$ & Purpose of visit \\
\hline Subject & $\langle\mathrm{SUB}\rangle$ & Subjects to be discussed \\
\hline Requester & $\langle\mathrm{REQ}\rangle$ & Visit requested by ERDA or ORNL division \\
\hline City & $<\mathrm{CITY}>$ & City of birth \\
\hline Country & «CNTRY $\rangle$ & Country of birth \\
\hline Portal & $<$ PORT $>$ & Portal to be entered \\
\hline Entry date & $<$ ENT DAT> & Date visitor entered facility \\
\hline Cleared & $<$ CLEAR $>$ & Individual clearing visitor for entry \\
\hline Status & $<$ STAT $>$ & Immigrant or nonimmigrant \\
\hline Security & $\langle\mathrm{SEC}\rangle$ & Individual in Security approving visit \\
\hline
\end{tabular}


Because security is a major concern with visitors, it may be advantageous to have a joint effort with the Security Department which would allow them to input to and search the data base. Security may also desire to add further information to the ORCHIS data base record for their own use.

PHOTOGRAPH DATA BASE

A computerized file for maintaining visual aids including photographs, charts, drawings, and graphs can be developed in a manner similar to the ORNL-3300 data base utilizing the ORCHIS system. In ORNL/TM-6039, Computerized Photographic Filing and Retrieval System by R. K. McConathy and $M$. Hoffman, such a system has been recommended for use in the Environmental Sciences Division (ESD). Included in this system are codes for entering data pertaining to type of photograph, photograph content, photograph material, drawings, and graphs. Since tle E3D photographic filing system has been developed and sample applications made (including the Laboratory Director's viewgraph file), the ESD work could be utilized in developing a similar system for LRD. Also, since the ESD system is based on the ORCHIS system, the mechanism for data entry and computer output would essentially be the same as for the ORNL-3300 data base and the foreign visitor data base.

An example of ORCHIS fleld identifiers and their meanings is given in Table 1. Modification of these fields to fit specific needs of LRD can be done with a minimum of effort. Sample searches showing the ease of retrieving a specific visual aid are given in Appendix 2 of ORNL/TM-6039.

\section{SYSTEM IMPLEMENTATION}

To implement the general recommendations outlined in this paper, the following tasks would be required (not necessarily in this order):

1. Purchase two computer terminals (Diablo), one for LRD and one for the area manager's office. Approximate cost is $\$ 6,000$ for two terminals. If a forms mode data entry terminal with local storage is desired, the cost for one hard copy terminal (Diablo) and one forms terminal (Hewlett Packard) is a total of $\$ 9,000$. 
2. Establish ORNL disk space area for data if the data base is to be accessed online through procurement of a disk drive $(\$ 20,000)$ or through loaned disk space from another division.

3. Train at least three LRD personnel in use of the terminal.

4. Establish appropriate ORCHIS fields for records in the LRD Information System data bases..

5. Set up the PDP-10 ADENTER program for prompted input of the data base fields or establish forms data entry software if a forms mode terminal is used.

6. Train at least one LRD staff member to run the ORCHIS software. Initially, Computer Sciences Division personnel could execute the ORCHIS software.

7. Alter LRD procedures to accommodate the new system.

8. Start initial testing of system by running in parallel for approximately one month.

9. After initial test period, review ORCHIS fields for any new fields which may be necessary and then implement new system.

10. Make arrangements to obtain past years' data (ORNL-3300) through either rekeying or by obtaining a magnetic tape from TIC. Keypunched information for past years has been discarded by SDO. 


\section{THIS PAGE}

\section{WAS INTENTIONALLY \\ LEFT BLANK}


ORNL/TM-6090

INTERNAL DISTRIBUTION

1. S. I. Auerbach

2. W. Fulkerson

3. H. F. McDuffie

4. L. J. Peck

5. H. Postma

6. C. E. Price

7. C. R. Richmond

8. C. R. Shriner

9. B. C. Talmi
10-19. G. U. U1rikson

20. ERC Resource Center, 2028

21. Biology Library

22-23. Central Research Library

24. Document Reference Section

25. ICC Resource Center, 7509

26-27. Laboratory Records

28. Laboratory Records, RC

29. ORNL Patent Office

\section{EXTERNAL DISTRIBUTION}

30. Theodore M. Albert, Acting Director, Environmental Information Systems, Office of Assistant Administrator for Environment and Safety, DOE, Washington, D.C. 20545.

31. William R. Bibb, Chief, Research and Development Branch, Research and Technical Support Division, DOE-ORO, Oak Ridge, Tennessee 37830.

32. Philip L. Johnson, Executive Director, Oak Ridge Associated Universities, P.0. Box 117, Oak Ridge, Tennessee 37830 .

33. Henry Kissman, Associate Director, Specialized Information Services, National Library of Medicine, 8600 Rockville Pike, Bethesda, Maryland 20014.

34. John H. Wilson, Jr., Analysis and Assessment Programs, DBER/DOE, Washington, D.C. 20545.

35-61. Technical Information Center, DOE, Oak Ridge, Tennessee 37830.

62. Research and Technical Support Division, DOE-ORO, Oak Ridge, Tennessee 37830 . 